\title{
The Relationship between Abnormal Growth of Inventory and Long-Term Stock Returns of Companies Listed in Tehran Stock Exchange
}

\author{
Hussein Teymoori', Faranak Khodayar ${ }^{2}$, Sedigheh Tootian Esfahani ${ }^{3}{ }^{*}$ \\ ${ }^{1}$ Electronic Branch, Islamic Azad University, Tehran, Iran \\ ${ }^{2}$ Depament of Business Management, Islamic Azad University, Firoozkooh, Iran \\ ${ }^{3}$ Department of Accounting, College of Humanities, Tehran East Branch, Islamic Azad University, Tehran, Iran \\ Email: "tootian.seda@gmail.com
}

Received 27 January 2016; accepted 28 May 2016; published 31 May 2016

Copyright (C) 2016 by authors and Scientific Research Publishing Inc.

This work is licensed under the Creative Commons Attribution International License (CC BY).

http://creativecommons.org/licenses/by/4.0/

\section{(c) (i) Open Access}

\begin{abstract}
This study aimed to investigate the impact of seasonal fluctuations in annual and long-term inventory on stock returns of companies listed on the Stock Exchange in Tehran. A sample of 84 listed in the Tehran Stock Exchange, which their data for a period of 5 years (1388 to 1392) were the statistical analysis. Model study of research Steinker and Hoberg (2014) has been adapted where long-term stock return as the dependent variable is a function of the independent variables. The findings suggest that there is a significant relationship between annual and seasonal abnormal growth of inventory and long-term stock returns. This finding indicates that the capital market has reacted to inventory changes at different times. Based on the above results, it can be covered in the basic hypotheses accepted.
\end{abstract}

\section{Keywords}

Annual Inventory Abnormal Growth, Abnormal Growth of Seasonal Inventory, Long-Term Stock Returns

\section{Introduction}

Investors and financial analysts are seeking a good payoff through anticipating stock price trend in future by analyzing the financial statements. One of the main items of assets in the balance sheet of manufacturing and

${ }^{*}$ Corresponding author.

How to cite this paper: Teymoori, H., Khodayar, F., \& Esfahani, S. T. (2016). The Relationship between Abnormal Growth of Inventory and Long-Term Stock Returns of Companies Listed in Tehran Stock Exchange. Journal of Financial Risk Management, 5, 81-93. http://dx.doi.org/10.4236/jfrm.2016.52009 
trading companies is inventory that its analysis is very important. Inventory is always a big part of the company's investments and resources consumption, and has been very important in terms of value, and consequently, significantly influence the activities of corporate profitability. On the importance of inventory, we should consider two aspects. On one hand, holding too much inventory can increase warehousing costs and the risk of unsuitablity of inventory, but make this advantage for the company that can be easily accountable to customers' need. On the other hand, lack of inventory makes that companies are unable to respond to their customers at the right time and that in the long run can lead to the loss of customers and reduce the profitability of the company. Since inventory is one of the most important items of current assets, given the absence of inflationary conditions, retention too much inventory can reduce internal efficiency. But in countries such as Iran that there is a high inflation rate, it may not lead to not only lower rates of returns but also eliminated loss of monetary items (Tribo, 2007).

\section{Literature Review}

Several studies have been conducted on the relationship between inventories, profitability and corporate performance. For example, Blinder and Makini (1991) argue that inventory management affects the performance of the company's in various ways. They also stated that by maintaining inventory, companies can improve production planning, minimize cost of lack or shortage of inventory and significantly reduce procurement costs through bulk purchases and speculation in the price deals. They suggest that in the meantime should never be ignored the maintenance costs, such as opportunity cost, space cost, transport costs, obsolescence, insurance, and wastes (Steinker \& Hoberg, 2014).

Decisions about the amount of inventory needed, granting trade credit to purchase or receive trade credit from suppliers of raw materials, including topics which could have affect the cash conversion cycle and ultimately affect the company's profitability (Deloof, 2005).

Because high abnormal fluctuations in seasonal inventory and abnormal growth of the annual inventory shows temporary mismatch between supply and demand, we expect this measurement is useful to transfer information about operational risks and encounter chance by the company. One of the issues considered in the analysis of the balance sheet by financial analysts is inventory changes as one of the main items of circulating capital and its analysis (Steinker \& Hoberg, 2014).

Tribo (2007) in a study review the effect of ownership structure on inventory policies in Spanish companies. The dependent variable was inventory level and independent variables, including institutional ownership and manager's ownership. They showed that the presence of institutional investors in the ownership structure of companies, reduce their needs to liquidity and prevent excessive investment. This leads to achieve a balanced inventory levels. The findings suggest that if financing through equity, the amount of resources invested in inventory is less than when financed through debt.

Rumyantsev and Netessine (2007b) study the impact of inventory policies on the financial performance, and they were examined relationship between inventory changes and return on assets (ROA). The method they used was correlation and mathematical model was multivariate regression. They concluded that there is significant relationship between inventory changes and return on assets (ROA).

Thomas and Zhang (2008), in a study investigate the relationship between changes in the company's inventory and future returns. The dependent variable is future stock returns and independent variable is the level of inventory. The method they used was correlation and mathematical model was multivariate regression. The results of their study showed that the inverse relationship between accruals items and future returns of the company has caused by changes in inventory. They stated that the inventory is a very important determining factor for the performance and value of companies.

Bernard and Noel (2009), in a study examine the issue whether the inventory forecasts, the company's profits and future sales? The results of a survey of 168 companies between 1999 and 2008 showed that there is direct relationship between inventories and profits and sales forecasts of company.

Bao and Bao (2010), in a study examine the impact of awareness of changes in inventories on the valuation of the company. The results showed that awareness of change in inventories is very useful for valuation of the company.

Ameer (2010) investigated the governmental role of institutional investors and domestic and foreign banks on 
financial decisions that have implications for liquidity, such as inventory management and cash management. The sample consists of companies listed in stock market of 6 Asian countries, during 2002 to 2005. The researcher found that foreign banks by supervisory role that managers have, improve inventory management and cash management strategies. Insufficient number of institutional investors in the industrial sector of Asian countries may be due to the industry of these countries, mainly consumer industry that institutional investors are keen to invest in them.

Basu and Wang (2011), in a study investigate the relationship between changes in inventories and value of the company and profits. The findings of their study, observed between 1950 and 2005 showed a negative relation- ship between changes in inventories and firm performance; however, this relationship are weak in wholesale and retaile industry and companies that normally hold down its inventory level. Basu and Wang (2011) found that the above factors can strengthen the relationship between changes in inventory and performance of company.

Kesavan and Mani (2012) are study the relationship between inventory abnormal growth and firms' future profitability, companies surveyed in the study, were retailing companies. The results showed that there is significant relationship between inventory abnormal growth and future profitability of retail companies.

Elsayed and Wahba (2013) in a study assumed that the relationship between institutional ownership and inventory management may be mediated due to other mechanisms of corporate governance. The results showed that there is a significant relationship between institutional ownership and inventory management. The results showed that this relationship is stronger and more meaningful in firms with high managerial ownership, bigger board size and CEO task duality.

Steinker and Hoberg (2014) examined the relationship between changes in inventory and long-term stock returns. They sample was US big manufacturing companies during 1991 and 2010. The results showed that there is significant relationship between seasonal changes in inventory and their abnormal growth with long-term changes in stock returns. According to the results, both measures cannot fully explain the company's overall risk. However, high changes in inventories and abnormally low growth, improved return on equity and stock performance decreased with increased abnormal growth. Therefore, it can be argued that a change in the level of inventory, reflect the potential risks and opportunities for companies.

\section{Research Methodology}

\section{Research method}

In terms of purpose, this study is an applied research and in terms of information gathering, is descriptive corelational. Since focuses on the relationships between variables and tries to prove this relationship based on historical data. Therefore, it can be classified as causal-comparative study.

Conceptual models and variables (Figure 1)

\section{The definition of variables}

Dependent variable

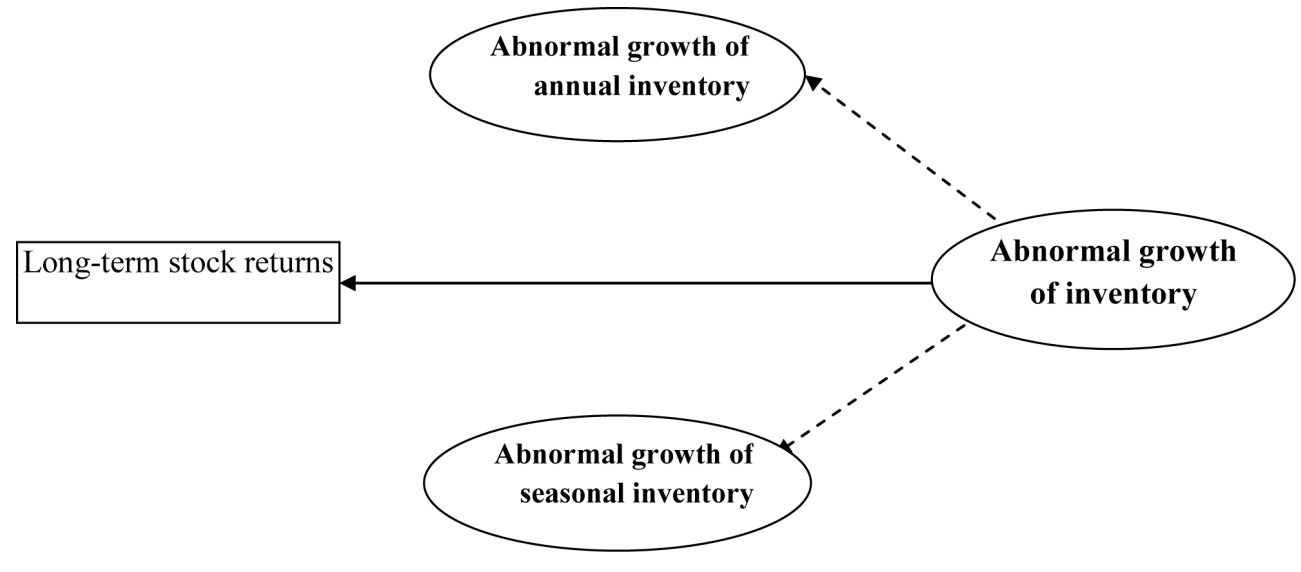

Figure 1. Conceptual model. 
- Long-term stock returns: Return on any equity calculated due to fluctuations in stock prices, dividends, interest and other cash and non-cash benefits contribution in a given fiscal period will be awarded to the holder of the share. Accordingly, the profitability of the companies in the sample, calculated as following.

$$
\operatorname{Ret}_{i, t}=\frac{\left(P_{i, t}-P_{i, t-1}\right)+D_{i, t}}{P_{i, t-1}}
$$

Ret: The total return on the company's shares during a financial year

$P$ : Price of shares in the capital market

$D$ : Distribution of the benefits of ownership of shares in the financial period includes dividends, bonus shares, precedence, etc. (Nikbakht \& Moradi, 2005).

\section{Independent variable}

1) Abnormal growth of annual inventory ( $A B I)$ : changes in inventory normally associated with the sale. In other words, the ratio of inventory depends to sales of a company, and in fact it can be argued that the ratio of inventories to sales is partly constant. Among other factors, such as the company's business model and inventory specific policies of the company, the ratio of inventory to sales dramatically changed compared to previous years, if growth of inventory is larger (lower) than sales growth it can indicate operational problems and may both contain important information regarding and financial status of a company. To calculate the abnormal growth of inventory, the inventory to sales ratio used during different periods (Steinker \& Hoberg, 2014).

To calculate the $A B I A_{i, t}$ variable, annual abnormal growth of inventory followed according to form of research Steinker and Hoberg (2014) and measured as follows:

$$
\begin{gathered}
A B I_{i, t}=\frac{\Delta I N V_{\mathrm{it}}}{\Delta \text { sales }_{\mathrm{it}}} \\
\Delta I N V_{\mathrm{it}}=\frac{1 / 4 \sum_{q=1}^{4} I N V_{i q t}}{1 / 4 \sum_{q=1}^{4} I N V_{\mathrm{it}-1 q}} \\
\Delta \text { sales }=\frac{\sum_{q=1}^{4} C O G S_{i t q}}{\sum_{q=1}^{4} G O G S_{\mathrm{it}-1 q}}
\end{gathered}
$$

$\triangle I N V_{\text {it }}$ is annual change in inventory; $\triangle C O G S_{\text {it }}$ is annual changes in cost of goods sold (Steinker \& Hoberg, 2014).

$\mathrm{Q}$ is annual season.

\section{2-Abnormal growth of seasonal inventory}

To calculate the $A B I Q_{i, t}$ variable, annual abnormal growth of inventory followed according to form of research Steinker and Hoberg (2014) and measured as follows:

$$
\begin{gathered}
A B I_{i, t}=\frac{\Delta I N V_{\mathrm{it}}}{\Delta \text { sales }_{\mathrm{it}}} \\
\Delta I N V_{\mathrm{it}}=\frac{I N V_{i q t}}{I N V_{\mathrm{it}-1 q}} \\
\Delta \text { sales }=\frac{C O G S_{i t q}}{G O G S_{\mathrm{it}-1 q}}
\end{gathered}
$$

$\triangle I N V_{\text {it }}$ is seasonal change in inventory and $\triangle C O G S_{\mathrm{it}}$ is seasonal change in cost of goods sold (Steinker \& Hoberg, 2014).

$\mathrm{Q}$ is annual season.

Control variables

1. Beta coefficient (systematic risk index)

Systemic risk (Beta) reflects the relationship between changing stock returns and stock market returns varia- 
bility. In this study, the following formula is used to calculate beta coefficient (Noravesh \& Dailami, 2005).

$$
\beta_{i}=\frac{\operatorname{Cov}\left(R_{\mathrm{it}} * R_{m}\right)}{\operatorname{Var}\left(R_{m}\right)}
$$

$R_{\mathrm{it}}$ : total Return of shares of company $i$ at time $t$ (including all cash benefits and changes in the stock price in the period $t$ )

$R_{m}$ : stock market returns in period $t$

2. Size: Company size is a measure that reflects the characteristics of the company. In this study, to measure the size of company the log value of the company's stock market value is used (Noravesh \& Dailami, 2005).

Size $=\operatorname{Ln}(M v)$

3. Market value to book value ratio $(M T B)$

This ratio is expressed as an index of growth opportunities for corporations and is calculated by the division of market value issued stock to book value of equity (Noravesh \& Dailami, 2005).

$$
M T B=\text { Book Value }
$$

4. Financial leverage

Ratio of debt to assets used as a criterion for determining the capital structure of the company. This measure that named financial leverage is defined as an indicator of financial risk, and ability to pay debt. In this study, financial leverage is an indicator of the company's debt level and borrowing capacity (Noravesh \& Dailami, 2005).

$$
\text { Lev }=\frac{\text { Total Debit }}{\text { Total Assets }}
$$

5. Return on asset (ROA)

Return on assets reflect the company's efficiency in the use of resources and is obtained from the ratio of net profit to total assets (Noravesh \& Dailami, 2005).

$$
R O A=\frac{\text { Net profit }}{\text { Total assets value }}
$$

\section{Variables classification}

Dependent variable

Long-term returns

Independent variables

1-Abnormal growth of annual inventory

2-Abnormal growth of seasonal inventory

\section{The relationship between variables}

The regression will be used to analyze the raw data and transform them into information needed to test the hypothesis and describe relationships between variables. The tests runs by SPSS software and at $95 \%$ level of confidence.

To test the hypotheses model provided by Steinker and Hoberg (2014) is used. These models are as follows.

\section{1-The first hypothesis test}

$$
\operatorname{Ret}_{i, t}=\beta_{0}+\beta_{1} A B I A_{i, t}+\beta_{2} \operatorname{Beta}_{i, t}+\beta_{3} \operatorname{Size}_{i, t}+\beta_{4} M T B_{i, t}+\beta_{5} \operatorname{Lev}_{i, t}+\beta_{6} R O A_{i, t}+\varepsilon_{i, t}
$$

Ret: annual return of company's shares (as the dependent variable)

$A B I A$ : unusual changes in Annual inventory of Company (as the independent variable)

Beta: systemic risk index (as a control variable)

Size: the size of the company (as a control variable)

$M T B$ : growth opportunities index (as a control variable)

Lev: financial leverage (as a control variable)

$R O A$ : return on assets (as a control variable)

In the above regression model, the coefficient $\beta_{1}$, shows the effect of annual unusual changes in inventory on 
long-term returns of a company. The coefficients $\beta_{2}$ to $\beta_{6}$ reflect the effect of control variables on long-term returns of the company. Accordingly, the decision of the first hypothesis is as follows.

$\mathrm{H} 0: \beta_{1}=0$

$\mathrm{H} 1: \beta_{1} \neq 0$

\section{1-The 2st hypothesis test}

$$
\operatorname{Ret}_{i, t}=\beta_{0}+\beta_{1} A B I Q_{i, t}+\beta_{2} \operatorname{Beta}_{i, t}+\beta_{3} \operatorname{Size}_{i, t}+\beta_{4} M T B_{i, t}+\beta_{5} \operatorname{Lev}_{i, t}+\beta_{6} R O A_{i, t}+\varepsilon_{i, t}
$$

Ret: annual return of company's shares (as the dependent variable)

$A B I Q$ : unusual changes in seasonal inventory of Company (as the independent variable)

Beta: systemic risk index (as a control variable)

Size: the size of the company (as a control variable)

$M T B$ : growth opportunities index (as a control variable)

Lev: financial leverage (as a control variable)

$R O A$ : return on assets (as a control variable)

\section{Statistical Society}

In this study to hypotheses testing classified and audited financial data of companies listed in Tehran Stock Exchange are used. The study population was 12 industrial group of companies listed on Tehran Stock Exchange. According to the study, inventory, is considered as one of the important factors, so in the industry selection have tried to sample industries that inventory management is considered to be important for them so that the effect of these strategies more clearly explained.

Metal products, basic metals group of companies, group of automobile companies and components manufacturing, Pharma group of companies, electric group of companies, metallic minerals, machinery and equipment, ceramic tiles, group of food companies, the group of chemical products companies, rubber and plastic, non-metallic minerals, cement, lime, plaster

The study population should have the following features.

Not to be among investment firms, insurance companies and banks.

During fiscal years 2009 to 2013 were present in stock exchange.

Do not stop trading symbol more than 4 months per year.

The end of their fiscal year was end of March each year and during the above mentioned period has not changed the fiscal year.

In all the years of study their annual financial data was available.

In all the years of study their seasonal financial data was available.

The company's equity is not negative any of years of research.

Population size, after the restrictions mentioned above, is 149 companies.

\section{Sample size, sampling methods}

The population size, after the restrictions mentioned in the prior paragraph, was 149 companies. Pilot sample, were considered 15 companies.

Thus, the sampling method is simple random because all the statistical population is quite the same chance to be selected and the results of the research can be generalized to the entire population. Also, study period is 5-year, including the years 2009 to 2013.

Data collection methods and their application

1) Library method

This method is used to collect data on literature and history of the research, including research papers, theses, books, articles, and...that the researcher can familiar with subject by them and see its dimensions and know more about purpose or goals of research.

2) Refer to the documentation method

This method is used to gathering data on past performance of relevant institutions, to analyze the hypothesis of this study, among this documents it can be mentioned the available management reports and notes along with financial statements of the firm.

Data collection tools and their application

The stock exchange data center

To collect and aggregate financial data published by the companies in the sample Tehran Stock Exchange databases was used and information of softwares of RAHAVARDNovin and Tadbirpardaz was used. 


\section{Data Analysis}

\section{Descriptive stats}

In order to analyze the data, at first we need to measured statistical data. Description of sample is a technique deals with central and dispersion data indices. Total views of research are 420 year-company. The observations arising from the combined data of 84 companies listed on the stock exchange as samples during the 5 years 2009 to 2013, as the period of test. Descriptive statistics of the variables used in the model to test hypotheses presented in Table 1.

Descriptive analysis, are given useful information about the distribution of the data collected and calculated variables to researchers. For example, the results presented in Table 1 show that the standard deviation obtained for the long-term return on equity is higher than the average for this variable. This finding suggests that the abnormality of the dependent variable and the presence of sharp fluctuations in the distribution of data that is important in the analysis of its behavior through regression models. Average of stock returns variable, 512/0, which shows the sample companies, on average, have $2 / 51$ percent yields to shareholders, during the investigation period.

The findings of the independent variables indicate that the average obtained for abnormal inventory annual growth variable, is higher than the average of abnormal growth of seasonal inventory. This finding indicates that the sample of companies it is more sensitive in the course of the annual inventory. Also, the standard deviation obtained for the abnormal inventory annual growth variable, is higher than the standard deviation of abnormal growth of seasonal inventory. In other words, companies in the sample in terms of annual growth of abnormal inventory, have more variability than seasonal growth.

Descriptive statistics for control variables shows that the average for financial leverage was 596/0 that indicate that nearly 60 percent of the assets of the companies in the sample are provided in debt form during the investigation period, The average for ratio of market value to book value, stating that the market value of companies in the sample during the investigation period, on average was more than 2 times of their book value. An average obtained for ROA is positive and shows that companies in the sample have gain more than $15 \%$ of its assets during the investigation period

\section{Regression Pre-Hypothesis analysis}

In this study, two hypotheses have been proposed and two regression models is fitted to analyze the relationships between variables. The validity of regression model is measured by the basic pre-assumptions of regression. These assumptions and their consequences for research models are as follows.

The normality of the dependent variables

In model of hypotheses testing, long-term return on equity is considered as the dependent variable. To assess the normality of the dependent variable as one of the classical assumptions of regression and validity of model, Jarque Bera test was used. Statistical hypothesis for this test is as follows.

H0: Distribution of data is normal.

H1: Distribution of data is not normal.

The results of this test are given in Table 2 .

Table 1. Descriptive statistics of variables

\begin{tabular}{|c|c|c|c|c|c|c|c|c|}
\hline Row & Size & ROA & $\begin{array}{l}\text { Market value to } \\
\text { book value }\end{array}$ & $\begin{array}{l}\text { Financial } \\
\text { Leverage }\end{array}$ & $\begin{array}{c}\text { Beta } \\
\text { coefficient }\end{array}$ & $\begin{array}{l}\text { Abnormal growth of } \\
\text { seasonal inventory }\end{array}$ & $\begin{array}{l}\text { Abnormal growth } \\
\text { of annual inventory }\end{array}$ & $\begin{array}{l}\text { Long-term } \\
\text { stock returns }\end{array}$ \\
\hline $\begin{array}{l}\text { Variable } \\
\text { symbol }\end{array}$ & SIZE & ROA & MTB & LEV & BETA & ABIQ & $\mathrm{ABI}$ & RET \\
\hline Average & $13.21,478$ & $0.156,176$ & $2.178,105$ & $0.596,470$ & $0.590,162$ & $0.800,042$ & $1.060,875$ & $0.512,946$ \\
\hline Median & $13.09,577$ & $0.117,936$ & $1.713,610$ & $0.609,151$ & $0.445,074$ & $0.697,991$ & $0.991,500$ & $0.257,283$ \\
\hline Max & $18.42,758$ & $0.695,370$ & $7.722,551$ & $0.991,793$ & $30.71,410$ & $3.924,475$ & $4.590,101$ & $3.720,067$ \\
\hline Min & $9.942,708$ & $-0.247,882$ & $0.144,845$ & $0.096,415$ & $-3.752,083$ & $0.181,941$ & $0.220,007$ & $-0.572,400$ \\
\hline S.D & $1.605,807$ & $0.159,381$ & $1.602,152$ & $0.183,324$ & $1.900,770$ & $0.396,979$ & $0.434,202$ & $0.814,605$ \\
\hline Skewness & $0.646,745$ & $0.868,176$ & $1.456,819$ & $-0.261,499$ & $10.81,646$ & $3.629,810$ & $2.961,338$ & $1.551,181$ \\
\hline Kurtosis & $3.388,801$ & $3.775,790$ & $4.900,834$ & $2.401,037$ & 162.7576 & $20.37,912$ & $19.65,695$ & $5.109,907$ \\
\hline $\begin{array}{c}\text { Observations } \\
\text { no }\end{array}$ & 420 & 420 & 420 & 420 & 420 & 420 & 420 & 420 \\
\hline
\end{tabular}


Given that a significant level of statistic is less than 0/05 (0.000), so the hypothesis H0 based on normal distribution of the dependent variable is rejected at $95 \%$ level of confidence. These findings suggest that dependent variable do not have a normal distribution.

Given the above, it is necessary to normalize the dependent variables before the hypothesis testing. In this study natural logarithm $(\mathrm{Ln})$ is used for normalizing the data. The results of Jarque Bera test after data normalization process are in Table 3.

According to the results, obtained significant level of Jarque Bera test for dependent variables is higher than the level of test error $(05 / 0=\alpha)$, and the hypothesis $\mathrm{H} 0$ will be accepted. In other words, data on the dependent variable after normalization have distribution close to the normal distribution and normality will be accepted as one of the basic regression assumptions about these variables.

Adjusted coefficients of determination obtained for fitted regression models in this study are as follows.

The results (Table 4) show that coefficients of determination for regression models is more than 3.0, and in fact, these models, explained more than 30 percent of changes in long-term stock return of company's performance through independent variables.

Linear independence of $x$ or independent variables of matrix correlation variables

The correlation matrix, is reflected the relationship between the two variables. This relationship is measured by Pearson correlation coefficient and allows researchers to obtain information about the presence or absence of collinearity between the independent variables of each model, before running regression models. Correlation matrix of variables is as follows (Table 5).

The relationship between independent variables shows that none of the correlation coefficients are not higher than 5.0 and in this respect, possibility of collinearity between the independent variables in the model of hypotheses test, is rejected.

Table 2. Normality test of the dependent variables.

\begin{tabular}{ccc}
\hline Significance level & Jarque Bera Statistics & Variables \\
\hline $000 / 0$ & $336 / 246$ & Long-term return \\
\hline
\end{tabular}

Table 3. Normality test of the dependent variable after normalization.

\begin{tabular}{ccc}
\hline Significance level & Jarque Bera Statistics & Variables \\
\hline $09 / 0$ & $03 / 4$ & Long-term return \\
\hline
\end{tabular}

Table 4. Adjusted coefficients of determination for fitted regression models.

\begin{tabular}{ccc}
\hline Coefficients of determination & Depende ntvariable & Model \\
\hline $329 / 0$ & Ret & The first hypothesis test model \\
$398 / 0$ & Ret & The second hypothesis test model \\
\hline
\end{tabular}

Table 5. Correlation matrix of variables used in the model of hypotheses test.

\begin{tabular}{|c|c|c|c|c|c|c|c|c|}
\hline Row & Size & ROA & $\begin{array}{l}\text { Market value to } \\
\text { book value }\end{array}$ & $\begin{array}{l}\text { Financial } \\
\text { Leverage }\end{array}$ & $\begin{array}{c}\text { Beta } \\
\text { coefficient }\end{array}$ & $\begin{array}{l}\text { Abnormal growth of } \\
\text { seasonal inventory }\end{array}$ & $\begin{array}{l}\text { Abnormal growth of } \\
\text { annual inventory }\end{array}$ & $\begin{array}{l}\text { Long-term } \\
\text { stock returns }\end{array}$ \\
\hline $\begin{array}{l}\text { Variable } \\
\text { symbol }\end{array}$ & SIZE & ROA & MTB & LEV & BETA & ABIQ & $\mathrm{ABI}$ & RET \\
\hline RET & & & & & & & & $1.000,000$ \\
\hline $\mathrm{ABI}$ & & & & & & & $1.000,000$ & $0.111,852$ \\
\hline ABIQ & & & & & & $1.000,000$ & $0.185,732$ & $-0.053,522$ \\
\hline BETA & & & & & $1.000,000$ & $-0.009,511$ & $0.138,334$ & $0.247,809$ \\
\hline LEV & & & & $1.000,000$ & $-0.044,128$ & $-0.041,871$ & $0.041,344$ & $-0.040,578$ \\
\hline МТВ & & & $1.000,000$ & $-0.011,939$ & $0.063,255$ & $0.065,483$ & $0.035,168$ & $0.398,217$ \\
\hline ROA & & $1.000,000$ & $0.249,680$ & $-0.642,131$ & $0.070,582$ & $0.031,868$ & $-0.069,280$ & $0.184,216$ \\
\hline SIZE & $1.000,000$ & $0.355,309$ & $0.405,518$ & $-0.152,296$ & $0.132,337$ & $0.043,510$ & $0.004,773$ & $0.359,324$ \\
\hline
\end{tabular}


The lack of Autocorrelation of residuals

To examine the lack of autocorrelation between the residuals of the regression model the Durbin-Watson statistic is used. The ideal range of this test is between $5 / 1$ and $5 / 2$. The results of this test for regression models presented in Table 6.

Since the Durbin-Watson statistic for each regression model, is at the desirable range, hypothesis of lack of autocorrelation between residuals will be accepted for the model.

Normality of residuals

If the fitted regression, is the best-fit for explaining the relationship between basic research variables, regression of residuals should be have normally distributed data, which showed symmetrical distribution of data on both sides of the regression line.

The results of the first hypothesis test

The model of this study is adapted from Steinker and Hoberg' work (2014), where stock returns as dependent variable is a function of abnormal growth of inventory and other independent variables. The results of the fitness of model are as follows.

A) The parameters and estimating equation table

Diagnostic tests of model

In order to fit the regression model, first appropriate regression model is identified through statistical tests. For this purpose, the Chow test procedures used. Chow test helps us to select best estimation method between the pooled method and panel. Thus, the regression model based on the combination, were fitted and then Chow test was conducted on the fitted regression. Statistical hypothesis for this test is as follows.

$\mathrm{H} 0$ : The regression method is pooled.

H1: The regression method is panel.

Given that a significant level of Chow test is lower than the error $(05 / 0)$, H0 hypothesis above, will be rejected. Accordingly, it is recommended to use the panel regression model to test hypotheses. In the models based on panel data, it is necessary to be tested the estimate method based on randomness or fixed effects, and chosen the most appropriate method for the model. In this regard, at first the regression model was fitted, based on a random effect and then, the method applied was checked through the Hausman test, Statistical hypothesis of Hausman test is as follows.

H0: Regressions is based on random effects.

H1: Regression is based on the fixed effects.

Based on the findings, a significant level of Hausman test is lower than $05 / 0$, so, using a fixed-effects regression model is recommended.

\section{Credit analysis of estimating equation}

Result of Statistical analysis about the validity of a regression models were noted in the second part of the above table. The coefficient of determination of regression model is 329/0 and suggests that this model is able to explain 32/9 percent of changes in the long-term return on stocks of sample companies through independent and control variables. The results also show that Durbin-Watson statistic is between $5 / 1$ and $5 / 2$ and therefore, there is not a strong autocorrelation between the errors of the regression model and the lack of autocorrelation between errors will be accepted, as one of the basic assumptions of the regression model about fitted model. Result of variance analysis of regression (ANOVA) that based on F statistic have the decisions about it for fitted models in first hypothesis test was shown in the last column of Table 7. Statistical hypothesis of the F statistic analysis is as follows.

$\mathrm{H} 0: \beta \mathrm{i}=0$ Regression model is not significant.

$\mathrm{H} 1: \beta \mathrm{i} \neq 0$ Regression model is significant.

Significance level of F statistic for the model is less than the test error $(\alpha=0 / 05)$ and therefore above H0 is rejected and estimated regression is statistically significant and the relationships between variables is linear.

Analysis of relationship between variables

Table 6. Test the lack of autocorrelation between the residuals of the regression model.

\begin{tabular}{ccc}
\hline Result & Durbin-Watson statistic & Model \\
\hline Lack of Autocorrelation & $926 / 1$ & The first hypothesis test model \\
Lack of Autocorrelation & $941 / 1$ & The second hypothesis test model \\
\hline
\end{tabular}


Table 7. Results of statistical analysis for the first hypothesis test.

\begin{tabular}{cccc}
\hline Variable & Level of significance & Statistic t & Coefficient $\beta$ \\
\hline C & 0.0000 & $-6.743,703$ & $-6.742,212$ \\
ABI & 0.0356 & $2.188,240$ & $0.098,933$ \\
BETA & 0.0003 & $3.666,652$ & $0.072,199$ \\
SIZE & 0.0000 & $7.097,935$ & $0.511,560$ \\
MTB & 0.0283 & $2.202,900$ & $0.090,290$ \\
LEV & 0.7061 & $0.377,480$ & $0.190,411$ \\
ROA & 0.5827 & $0.550,045$ & $0.238,195$ \\
\hline
\end{tabular}

Adjusted coefficient of determination: 329/0; F statistic Chow: 407/14; Durbin-Watson statistic: 926/1; F Chow significant level: 000/0; Statistic F 314/3; Hausman statistic: 839/13; The significant level of statistics F: 000/0; The significant level of Hausman: 031/0. The dependent variable: Ret.

According to the results presented in the above table, the estimated coefficient for the ABI variable that shows the relationship between the growth of abnormal annual inventory and long-term returns of stocks is equal to $0 / 098$ and with significant level of 0/035 that is less than $05 / 0$. These findings suggest a direct relationship between these variables and are adopted with the claims made in the first hypothesis. In other words, companies that have more unusual growth in inventory have experienced higher stock returns. This finding is adopted with the claims made in the first hypothesis and as a result, the first hypothesis will be accepted at 95 percent level of confidence.

Findings of the control variables suggest that there is a significant and direct relationship between the long term returns of stocks with variables of $\beta$, systemic risk, company size and the ratio of market value to book value. In other words, stocks with higher risk, have more returns and companies with bigger size and more the market value ratio, have higher yields to its shareholders.

The model of this study is adapted from Steinker and Hoberg' work (2014), where stock returns as dependent variable is a function of abnormal growth of inventory and other independent variables. The results of the fitness of model are as follows.

A) The parameters and estimating equation table

\section{Diagnostic tests of model}

In order to fit the regression model, at first appropriate regression model is identified through statistical tests. For this purpose, the Chow test procedures used. Chow test helps us to select best estimation method between the pooled method and panel. Thus, the regression model based on the combination, were fitted and then Chow test was conducted on the fitted regression. Statistical hypothesis for this test is as follows.

H0: The regression method is pooled.

H1: The regression method is panel.

Given that a significant level of Chow test is lower than the error (05/0), H0 hypothesis above, will be rejected. Accordingly, it is recommended to use the panel regression model to test hypotheses. In the models based on panel data, it is necessary to be tested the estimate method based on randomness or fixed effects, and chosen the most appropriate method for the model. In this regard, at first the regression model were fitted, based on a random effects and then, the appropriateness of method applied was checked through the Hausman test, Statistical hypothesis of Hausman test is as follows.

$\mathrm{H} 0$ : Regressions is based on random effects.

H1: Regression is based on the fixed effects.

Based on the findings, a significant level of Hausman test is lower than $05 / 0$, so, using a fixed-effects regression model is recommended.

Credit analysis of estimating equation

Result of Statistical analysis about the validity of a regression models were noted in the second part of the above table. The coefficient of determination of regression model is $398 / 0$ and suggests that this model is able to explain 39/8 percent of changes in the long-term return on stocks of sample companies through independent and control variables. The results also show that Durbin-Watson statistic is between $5 / 1$ and $5 / 2$ and therefore, there is not a strong autocorrelation between the errors of the regression model and the lack of autocorrelation between errors will be accepted, as one of the basic assumptions of the regression model about fitted model. Result 
Table 8. Results of statistical analysis for the second hypothesis test.

\begin{tabular}{cccc}
\hline Variable & T statistic & Coefficent $\beta$ & Variable \\
\hline C & $-6.630,503$ & $-6.673,619$ & Significant level \\
ABIQ & $2.740,019$ & $0.076,005$ & 0.0000 \\
BETA & $3.860,014$ & $0.075,363$ & 0.0198 \\
SIZE & $7.082,338$ & $0.511,567$ & 0.0001 \\
MTB & $2.199,154$ & $0.090,262$ & 0.0000 \\
LEV & $0.675,328$ & $0.335,239$ & 0.0286 \\
ROA & $0.677,681$ & $0.295,093$ & 0.4999 \\
\hline
\end{tabular}

Adjusted coefficient of determination: 398/0; F statistic Chow 443/12; Durbin-Watson statistic: 941/1; F Chow significant level: 000/0; Statistic F: 296/3; Hausman statistic: 811/80; The significant level of statistics F: 000/0; The significant level of Hausman: 000/0; The dependent variable: Ret.

of variance analysis of regression (ANOVA) that based on F statistic have the decisions about it for fitted models in first hypothesis test was shown in the last column of Table 8. Statistical hypothesis of the F statistic analysis is as follows.

$\mathrm{H} 0: \beta \mathrm{i}=0$ Regression model is not significant.

$\mathrm{H} 1: \beta \mathrm{i} \neq 0$ Regression model is significant.

Significance level of F statistic for the model is less than the test error $(\alpha=0 / 05)$ and therefore above H0 is rejected and estimated regression is statistically significant and the relationships between variables is linear.

Analysis of relationship between variables

According to the results presented in the above table, the estimated coefficient for the ABIQ variable that shows the relationship between the growth of abnormal seasonal inventory and long-term returns of stocks is equal to $0 / 076$ and with significant level of $0 / 019$ that is less than $05 / 0$. These findings suggest a direct relationship between these variables and are adopted with the claims made in the second hypothesis. In other words, companies that have more unusual growth in inventory have experienced higher stock returns. This finding is adopted with the claims made in the second hypothesis and as a result, the second hypothesis will be accepted at 95 percent level of confidence.

Findings of the control variables suggest that there is a significant and direct relationship between the long term returns of stocks with variables of $\beta$, systemic risk, company size and the ratio of market value to book value. In other words, stocks with higher risk, have more returns and companies with bigger size and more the market value ratio, have higher yields to its shareholders.

\section{Conclusion}

In general, the basic aim of this study was to determine the relationship between abnormal growth of inventory and long-term stock returns of companies listed on the Stock Exchange in Tehran. In this regard, a main hypothesis and tow sub-hypothesis were hypothesized and were statistically analyzed. The results of the hypotheses test were presented and results of the study were interpreted based on theoretical principles. Also, these results were compared with results of previous studies.

\section{Summary of Findings}

Inventories are one of the critical factors of achievement to the long-term and short-term goals of companies. Changes in the level of inventories in some way are associated with the increase or decrease in the company's liquidity and sales of companies, therefore, rise and fall of the company's sales are somehow linked to the financial strength of companies (Bao \& Bao, 2010). Most companies, according to their policies related to long-term goals, following the increase of the company's inventory to create equilibrium in productions and balance in production, require balancing in sales of company (Elsayed, 2011). Since abnormal fluctuations in seasonal inventory and abnormal growth of the annual inventory show temporary mismatch between supply and demand, we expect this measure is useful to transfer information about operational risks and opportunities faced by the Company. One of the issues considered in the analysis of the balance sheet by financial analysts, is inventory changes as one of the main items of working capital and its analysis. 
Table 9. Summary of results of the research.

\begin{tabular}{ccccc}
\hline Result & $\begin{array}{c}\text { Significant } \\
\text { level }\end{array}$ & $\begin{array}{c}\text { Independent variables } \\
\text { coefficent }\end{array}$ & $\begin{array}{c}\text { Independent } \\
\text { variables }\end{array}$ & Summary of hypothesis \\
\hline Accepted & 0.0356 & $0.098,933$ & ABI & $\begin{array}{c}\text { There is a direct relationship between annual inventory } \\
\text { abnormal growth and long-term return on stocks }\end{array}$ \\
Accepted & 0.0198 & $0.076,005$ & ABIQ & $\begin{array}{c}\text { There is a direct relationship between seasonal inventory } \\
\text { abnormal growth and long-term return on stocks }\end{array}$ \\
\hline
\end{tabular}

Due to the impact of inventory changes on financial decisions and their operational environment, the main focus of the research is the uncertainty in the capital market reaction to these changes and how to analyze it from investor's view. Clearing this could potentially help managers in order to select the correct working capital and inventory management strategies. In such way that they can adopt procedures that lead to the positive reaction of the capital market and enhance the company's market value. In this study, potentially, it has been emphasized on the relationship between the growth of abnormal inventory, in seasonal and annual levels and stock returns. The sample is 84 companies listed in the Tehran Stock Exchange and their data were analyzed for a period of 5 years (2009 to 2013). The model of this study is adapted from Steinker and Hoberg' work (2014), where stock return as dependent variable is a function of independent variables.

The findings (Table 9) indicated that there is a significant relationship between the annual growth of abnormal inventory and of abnormal growth seasonal inventory and long-term stock returns. This finding indicates that the capital market has reacted to the inventory changes at different times. Based on the above results, it can be accepted the basic hypotheses.

Based on theoretical and empirical findings of the first research hypothesis, it can be argued that the capital market reacts to information about management of inventory. In other words, such information is useful to investors. The results, in addition to confirming the importance of changes information of inventory in investors' decisions, suggest that the market reaction to the growth of inventories has been positive. In this regard, it is argued that the capital market point of view on working capital management probably has been based on the grounds that investing on inventory can be useful for the company and can improve its performance. It seems that the origin of this view is influenced by the theory of free cash flow that according to it, surplus cash resources in the company reduce the efficiency of resources and decrease performance of investment.

The results show that there is a direct relationship between the abnormal growth of seasonal inventory and long-term return on stocks. The findings explain that the inventory management strategies have been very important for capital market. So those market practitioners also have regarded the mid-term and seasonal inventory of companies in addition to observing the information about annual changes of inventory. Moreover, as the results of the first hypothesis, however, the response to growth of inventory is positive, and increases the return on equity.

\section{References}

Ameer, R. (2010).The Role of Institutional Investors in the Inventory and Cash Management Practices of Firms in Asia. Journal of Multinational Financial Management, 20, 126-143. http://dx.doi.org/10.1016/j.mulfin.2010.07.001

Bao, A., \& Bao, D. (2010). Taking Stock: A Critical Assessment of Recent Research on Inventories. Journal of Economic Perspectives, 5, 73-96.

Basu, N., \& Wang, X. (2011). Evidence on the Relationship between Inventory Changes, Earnings and Firm Value. The International Journal of Business and Finance Research, 3, 1-15.

Bernard, V., \& Noel, J. (2009). Do Inventory Disclosures Predict Sales and Earnings? Journal of Accounting, Auditing and Finance, 6, 82-145.

Blinder, A. S., \& Maccini, L. J. (1991) The Resurgence of Inventory Research: What Have We Learned? Journal of Economic Surveys, 5, 291-328.

Deloof, M. (2005). Dose Working Capital Management Affect Profitability of Belgian Firms? Journal of Business, Finance and Accounting, 30, 576-587.

Elsayed, K. (2011). Board Size and Corporate Performance: The Missing Role of Board Leadership Structure. Journal of Management and Governance, 15, 415-446.

Elsayed, K., \& Wahba, H. (2013). Reinvestigating the Relationship between Ownership Structure and Inventory Manage- 
ment: A Corporate Governance Perspective. Production Economics, 143, 207-218.

Kesavan, S., \& Mani, V. (2012) The Relationship between Abnormal Inventory Growth and Future Earnings for US Public Retailers. Manufacturing and Service Operations Management, 1-18.

Nikbakht, M., \& Moradi, M. (2005). Evaluation of Overreaction of Common Stockholders in the Tehran Stock Exchange. The Iranian Accounting and Auditing Review, 40, 97-130.

Noravesh, I., \& Deilami, Z. D. (2005). Financial Management (Vol. 1, p. 67). Tehran: Tehran University Press.

Rumyantsev, S., \& Netessine, S. (2007b) What Can Be Learned from Classical Inventory Models? Across-Industry Exploratory Investigation. Manufacturing \& Service Operations Management, 9, 409-429.

Steinker, S., \& Hoberg, K. (2014). The Impact of Inventory Dynamics on Long-Term Stock Returns-An Empirical Investigation of U.S. Manufacturing Companies. Journal of Operations Management, 31, 250-226.

http://dx.doi.org/10.1016/j.jom.2013.05.002

Thomas, J. K., \& Zhang, H. (2008). Inventory Changes and Future Returns. Review of Accounting Studies, 7, 163-187.

Tribo, J. (2007). Ownership Structure and Inventory Policy. International Journal of Production Economics, 108, 213-220. 